\title{
A novel update on vitamin $D$ in recurrent pregnancy loss (Review)
}

\author{
HAOYU ZHAO $^{1 *}$, XIAOQI WEI $^{2 *}$ and XIUHUA YANG ${ }^{2}$ \\ Departments of ${ }^{1}$ Hepatobiliary Surgery and Organ Transplant and ${ }^{2}$ Obstetrics, \\ The First Hospital of China Medical University, Shenyang, Liaoning 110001, P.R. China
}

Received September 27, 2020; Accepted February 15, 2021

DOI: $10.3892 / \mathrm{mmr} .2021 .12021$

\begin{abstract}
Recurrent pregnancy loss (RPL) is usually characterized as $\geq 3$ miscarriages before 20 weeks of gestation. Patients with RPL may have autoimmune abnormalities or alloimmune problems. Vitamin D has a major function on the mechanism of immunomodulation at the maternal-fetal interface. However, whether vitamin D can be used as an effective method to treat patients with RPL requires investigation. It has been reported that vitamin $\mathrm{D}$ could prevent the occurrence of antiphospholipid syndrome (APS) by reducing the expression levels of anti- $\beta 2$ glycoprotein and tissue factor in RPL cases with APS. In addition, there is an opposite relationship between vitamin $\mathrm{D}$ and thyroid peroxidase antibody levels in autoimmune thyroid disease cases with RPL. Vitamin D changes the ratio of T helper (Th) $1 / \mathrm{Th} 2$ and regulatory $\mathrm{T}$ cell/Th17 to a certain extent, as well as affects the activity of natural killer cells and the production of cytokines to reduce the incidence of RPL. The objective of the current review was to address the research progress of vitamin $\mathrm{D}$ in RPL in recent years, which could facilitate the use of vitamin $\mathrm{D}$ treatment to enhance the pregnancy outcome of RPL. Collectively, it was suggested that vitamin D may be used as an important and effective immunotherapeutic agent for patients with RPL.
\end{abstract}

Correspondence to: Dr Xiuhua Yang, Department of Obstetrics, The First Hospital of China Medical University, 155 Nanjing North Street, Shenyang, Liaoning 110001, P.R. China

E-mail: 57470040@qq.com

${ }^{*}$ Contributed equally

Abbreviations: RPL, recurrent pregnancy loss; APAs, antiphospholipid antibodies; ANAs, antinuclear antibodies; NK cells, natural killer cells; VDR, vitamin D receptor; VDD, vitamin D deficiency; VDL, low vitamin D; APS, antiphospholipid syndrome; TF, tissue factor; VDN, normal vitamin D; AITD, autoimmune thyroid disease; anti-TPO, thyroid peroxidase antibodies; VDI, vitamin D insufficient; Treg, regulatory T cell; G-CSF, granulocyte colony-stimulating factor

Key words: vitamin D, RPL, autoimmunity, cellular immunity, NK cells

\section{Contents}

1. Introduction

2. Vitamin D and antiphospholipid syndrome (APS) in RPL

3. Vitamin D and autoimmune thyroid disease (AITD) in RPL

4. Vitamin D and Th1/Th2 ratio in RPL

5. Vitamin D and Treg/Th17 ratio in RPL

6. Vitamin D and peripheral NK cells in RPL

7. Vitamin D and cytokines in RPL

8. Conclusions

\section{Introduction}

Recurrent pregnancy loss (RPL) is usually characterized as $\geq 3$ miscarriages before 20 weeks of gestation, but an increasing number of researchers describe it as $\geq 2$ spontaneous abortions (1). The etiology of RPL is multifactorial (2), including chromosomal abnormalities, genetic issues (3), congenital uterine defects, acquired or hereditary thrombotic diseases, endocrine issues, infections, autoimmune diseases and male factors (4). However, $\sim 50 \%$ of patients with RPL do not have a definite etiology (5). Patients with RPL may also have autoimmune abnormalities or alloimmune problems (2). The former mainly includes antiphospholipid antibodies (APAs) (6), antithyroid antibodies (7) and antinuclear antibodies (ANAs) $(8,9)$, while the latter mainly refers to cellular immune problems, such as increased natural killer (NK) cells (10-12) or decreased inhibitory $\mathrm{T}$ cells (13). Therefore, the success of pregnancy depends to a large degree on the development of an appropriate immune response (14).

It has been suggested that in patients, RPL, is largely associated with immune abnormalities (14), thereby contributing to the development and use of different forms of immunomodulatory therapies (1). Prednisone has been reported to help women who have multiple consecutive abortions by reducing inflammation and inhibiting the function of multiples types of immune cells, including $\mathrm{T}$ cells $(15,16)$. Moreover, plaquenil can be useful in the treatment of RPL as a drug with comprehensive protection identified during pregnancy (17). The therapeutic role of plaquenil is associated with pharmacological properties, such as antithrombotic activity, vascular defense, immunomodulation, improved glucose resistance, hypolipidemic 
activity and anti-infection function (17). Several studies have revealed that intravenous immunoglobulin modulated immune dysfunction and contributed to positive pregnancy outcomes in women with RPL, although controversial results have been reported (18-23).

In humans, vitamin D is involved in the metabolism of numerous elements, such as calcium and phosphorus (24). Vitamin D is a crucial modulator of essential biological effects, such as immune function and hormone secretion via the vitamin D receptor (VDR) (25). Vitamin D affects the innate and acquired immune response (26), as well as exerts an inhibitory function on the adaptive immune system (27). In comparison, it inhibits T helper (Th)1 cytokines (such as IFN- $\gamma$ ), and promotes the response of Th2 by both downregulating IFN- $\gamma$ and upregulating IL-4 (26). As VDR is expressed in the placenta, and it has been suggested that vitamin D has a major function on the mechanism of immunomodulation at the maternal-fetal interface (28). In the clinical setting, multiple patients with RPL have vitamin D deficiency (VDD) (29). As a result, these women have impaired cellular immune systems, including elevated peripheral NK levels, NK cytotoxicity and higher Th1/Th2 ratios (30-32). Moreover, women with low vitamin D (VDL) levels are more susceptible to autoimmune defects (29). For example, the decreased expression of vitamin D is associated with a higher occurrence of APAs, ANAs, anti-single stranded DNA and thyroid peroxidase antibodies (anti-TPO) in patients with RPL (27).

Few foods contain vitamin D (33), and vitamin D supplementation could be applied as a natural therapy to minimize the risk of spontaneous early abortion (4). However, excessive vitamin D intake can have adverse effects (34). For example, excessive vitamin D molecules can affect the production of oocytes and the quality of embryos due to their anti-estrogen effect (34). It is also important to periodically measure vitamin $\mathrm{D}$ levels and change the therapy during pregnancy (4). In clinical trials, doctors may neglect vitamin D intake partly due to the lack of knowledge of the mechanism of vitamin D in RPL (4). The objective of the present review was to address the research progress of vitamin D in RPL in recent years, which could facilitate the use of vitamin $\mathrm{D}$ treatment to enhance the pregnancy outcome of RPL. In total, two independent researchers searched for articles in PUBMED with the following medical subject heading: 'Vitamin D', 'RPL', 'recurrent miscarriages', 'autoimmunity', 'cellular immunity' or '1,25-dihydroxy vitamin D'. All articles were published in English between January 1995 and August 2020. Review manuscripts and letters were excluded.

\section{Vitamin D and antiphospholipid syndrome (APS) in RPL}

As an autoimmune disease, APS is closely associated with adverse obstetrical outcomes $(32,35)$. APS is a systemic autoimmune disease characterized by thrombosis (36). It has been well documented that the increased susceptibility to the thrombosis of blood vessels in APS may lead to microvascular thrombus in the placenta, as well as the reduction of blood flow at the maternal-fetal interface $(6,37)$. A significant crosstalk between inflammation and coagulation involves the complement system and tissue factor (TF), and both mice and humans experience APS-related pregnancy complications (38-40).

As aforementioned, complement activation serves a critical function in adverse outcomes of pregnancy, including RPL with APS in both mice and humans (41-46). Vitamin D can enhance the level of complement inhibitor CD55 in human monocytes (47). Moreover, the related inhibitory effect of complement activation can prevent preterm birth observed in APS (47). In patients with APS, vitamin $D$ exerts a suppressive effect on anti- $\beta 2$ glycoprotein expression, thus decreasing the risk of thrombosis $(48,49)$. Furthermore, as shown in in vitro studies, APA-induced TF expression was suppressed by vitamin D $(36,48)$. Another study reported that vitamin D regulated TF in vascular smooth muscle cells (50). In addition, abnormal $\mathrm{TF} /$ protease activated receptor 2 signaling was considered to be involved in the pathogenesis of pregnancy-associated complications, which included abortions in an APS murine model (38). The frequency of APS antibodies in women with RPL is $15-20 \%$ (51). Researchers have confirmed that VDD in APS women with RPL was more common relative to normal controls (49.5 vs. $30 \%$; $\mathrm{P}<0.05$ ) (48). Additionally, women with VDD were found to have enhanced levels of several autoantibodies, including APAs (29). The prevalence of total APA in women with RPL was substantially increased in VDL relative to a normal vitamin D $(\mathrm{VDN})$ group (39.7 vs. $22.9 \% ; \mathrm{P}<0.05$; odds ratio $=2.22$; 95\% CI, 1.0-4.7) (29). In brief, VDD is more common in RPL cases with APS. Moreover, an increased percentage of patients with RPL and VDD are at risk of autoimmune abnormalities, including APS (29).

\section{Vitamin D and autoimmune thyroid disease (AITD) in RPL}

Accumulating evidence has suggested that thyroid autoimmunity is the cause of miscarriage during pregnancy $(52,53)$. An increased morbidity of VDD was observed among patients with AITDs, in particular, Hashimoto's thyroiditis (54). Although the mechanisms underlying the relation between vitamin D and AITDs are not fully understood, the causes may be associated with anti-inflammatory and immunomodulatory functions (55). An opposite relationship between vitamin D and anti-TPO levels has been identified in women with AITD (56). Decreased levels of anti-TPO result in lower incidence of preterm birth and reduced rates of pregnancy loss (57). Antithyroid antibodies are more prevalent in patients with VDD compared with those with high levels of vitamin D (43 vs. 17\%, respectively; $\mathrm{P}<0.001)(54)$. Women with abnormal thyroid autoantibodies also had lower levels of vitamin D compared with healthy controls (54). Lower thyroid stimulating hormone levels are directly associated with a higher vitamin D level (54). Ozkan et al (58) revealed that 25(OH)-D in follicular fluid could independently predict successful pregnancy during the in vitro fertilization cycle. For women whose vitamin D levels in follicular fluid were $<10 \mathrm{ng} / \mathrm{ml}$, the presence of clinical pregnancy reduced significantly, while for patients 
whose vitamin D levels in follicular fluid increased by $1 \mathrm{ng} / \mathrm{ml}$, the rate of clinical pregnancy was enhanced by $6 \%$ (58). Moreover, vitamin D can activate HOX genes, including HOXA10, which is essential for the process of implantation (59).

\section{Vitamin $D$ and $T h 1 / T h 2$ ratio in $R P L$}

Vitamin D suppresses the proliferation of Th1 cells and restricts the secretion of cytokines, including IFN- $\gamma$, IL-2 and TNF- $\alpha$ (29). Moreover, vitamin D postpones subsequent antigen presentation and the accumulation of $\mathrm{T}$ lymphocytes by suppressing the transcription of IFN- $\gamma$, which is the main positive response symbol for antigen-presenting cells (60). Vitamin D also prevents the activation and spread of IL-2, which is the autocrine growth factor for T lymphocytes (61). By decreasing the synthesis of IL- 2 and IFN- $\gamma$ and inducing the polarization of $\mathrm{CD}^{+} \mathrm{T}$ lymphocytes to a $\mathrm{Th} 2$ reaction, as well as finally reducing the autoimmune response, vitamin D increases the secretion of Th2 cytokines (62), including IL-4, IL-5, IL-6, IL-9, IL-10 and IL-13 $(63,64)$. In a trial with mice, there was an increased accumulation of Th2 cells and higher counts of cytokines (IL-4, IL-5 and IL-10) when $1,25(\mathrm{OH})_{2} \mathrm{D}_{3}$ was administered (65). The $1,25(\mathrm{OH})_{2} \mathrm{D}_{3}$-related functions on the augment of Th2 cells were mainly regulated via IL-4 (62). The phenomenon could also be confirmed in the mouse model (66).

Excessive inflammatory response and lower levels of vitamin D are found in women with RPL (67). As observed in a previous study, patients with VDD showed an notable higher percentage of TNF- $\alpha$-secreting Th cells relative to individuals with normal vitamin D levels $(35.1 \pm 10.2$ vs. $28.3 \pm 4.8 \%$; $\mathrm{P}<0.05$ ), whereas the difference between vitamin $\mathrm{D}$ insufficient group (VDI) and VDN was negligible (2). In women with elevated vitamin $\mathrm{D}$ concentrations, the mean serum TNF- $\alpha$ was substantially lower compared with those with low vitamin D expression $(0.79 \pm 0.11$ vs. $1.22 \pm 0.11 \mathrm{pg} / \mathrm{ml}$; $\mathrm{P}=0.02)(68)$.

In a retrospective cross-sectional analysis conducted by Ota et al (29), it was observed that external vitamin D promoted $\mathrm{Th} 2$ polarization in a dose-dependent manner. In total, 70 women with VDN and 63 women with VDL were analyzed in this previous study (29). T cell cultures were supplied with $100 \mathrm{nM}$ vitamin $\mathrm{D}$ for $16 \mathrm{~h}$, and it was found that the TNF- $\alpha / \mathrm{IL}-10$ expressed $\mathrm{CD}^{+} / \mathrm{CD}^{+}{ }^{+}$cell ratio was substantially decreased $(31.3 \pm 9.4)$ relative to the controls $(40.4 \pm 11.3 ; \mathrm{P}<0.05)$ (29). However, when $10 \mathrm{nM}$ vitamin $\mathrm{D}$ was applied to $\mathrm{T}$ cells, no statistically significant difference was observed relative to the controls (29). After treatment with $100 \mathrm{nM}$ vitamin D, the IFN- $\gamma / \mathrm{IL}-10$ expressed $\mathrm{CD}^{+} / \mathrm{CD}^{+}{ }^{+}$cell ratio was also notably decreased compared with the controls $(12.1 \pm 4.0$ vs. $14.8 \pm 4.6 ; \mathrm{P}<0.05)(29)$, whereas there was no significant difference after adding $10 \mathrm{nM}$ vitamin D compared with controls (29). During this study (29), no significant difference was found in the Th1/Th2 cytokine-expressed $\mathrm{CD}^{+} / \mathrm{CD}^{+}{ }^{+} \mathrm{Th}$ cell ratio among VDL cases with RPL compared with VDN cases with RPL. Since it has been reported that only the treatment of $100 \mathrm{nM}$ vitamin $\mathrm{D}_{3}$ can affect the Th1/Th2 shift in vitro, the difference in average vitamin D levels between VDL and
VDN for the study may not be sufficient to change the ratio of Th1/Th2 in vivo (29). There is a relatively small difference in immunological biomarkers of normal vitamin D cases compared with low vitamin D cases in this study, and they may not have a strong clinical correlation with vitamin D levels.

Other studies have suggested that vitamin D could exert a vital influence on preventing excessive adaptive immune response among patients with RPL $(2,29,69)$. In one study, women with RPL were classified into three groups based on vitamin D level in serum: VDN, VDI and VDD groups (2). The definition of VDD was a level of $25(\mathrm{OH}) \mathrm{D}$ at $<20 \mathrm{ng} / \mathrm{ml}$, and VDI was defined as levels between 20-30 ng/ml, according to previously published literature (70). In 35 VDI cases, $0.5 \mu \mathrm{g} /$ day $1,25(\mathrm{OH})_{2} \mathrm{D}$ was applied for 2 months, and two patients with VDD were treated with the same amount of $1,25(\mathrm{OH})_{2} \mathrm{D}$. There was a substantial decrease in the proportion of TNF- $\alpha$-producing Th cells following treatment compared with that observed before treatment, whereas there was no obvious difference in the proportion of IFN- $\gamma$-producing Th cells between preand post-treatment (2). However, other research regarding $\mathrm{CD}^{+} \mathrm{T}$ cells in human has indicated that $1,25(\mathrm{OH})_{2} \mathrm{D}$ could decrease both the production of IFN- $\gamma$ and the numbers of IFN- $\gamma^{+} \mathrm{CD}^{+}{ }^{+} \mathrm{T}$ cells $(71,72)$.

\section{Vitamin $D$ and regulatory $T$ cell (Treg)/Th17 ratio in RPL}

Decreased Treg cells and increased Th17 cells serve a vital role in the pathogenesis of RPL (73). Due to VDD in pregnancy, the activity of Treg cells is disrupted (74). It has been reported that population of Treg cells was lower (maternal, $0.2 \pm 0.01$; cord, $0.63 \pm 0.03)$ in $25(\mathrm{OH}) \mathrm{D}_{3}$ deficient pregnant women $(\leq 19 \mathrm{ng} / \mathrm{ml} ; \mathrm{n}=80)$ compared with insufficient $(20-29 \mathrm{ng} / \mathrm{ml}$; $\mathrm{n}=55$; maternal, $0.34 \pm 0.01$; cord, $1.05 \pm 0.04)$ and sufficient ( $\geq 30 \mathrm{ng} / \mathrm{ml} ; \mathrm{n}=18$; maternal, $0.45 \pm 0.02$; cord, $1.75 \pm 0.02$ ) pregnant women $(\mathrm{P}<0.05)(74)$. When compared with insufficient and sufficient vitamin D levels, TGF- $\beta$ and IL-10 levels were decreased in the $25(\mathrm{OH}) \mathrm{D}_{3}$ deficient pregnancy group (74). Other studies have revealed that 1,25 vitamin $\mathrm{D}$ treatment significantly augmented the percentage of Tregs from baseline in the patients with RPL compared with the same percentage in the control group $(69,75,76)$.

A double-blind placebo-controlled analysis identified that vitamin $\mathrm{D}_{3}$ reduced the frequency of Th17, as well as decreased the Th17/Treg ratio in peripheral blood of women with RPL (77). In total, 44 women with RPL were involved in this research and were randomly assigned to the treatment $\left[\mathrm{n}=22\right.$; one $300,000 \mathrm{IU}$ dose of intramuscular vitamin $\mathrm{D}_{3}$ and Lymphocyte Immune Therapy (LIT)] and control $(n=22$; one dose of packaged inert placebo and LIT) groups (77). The findings revealed that the average proportion of Th17 cells and Th17/Treg ratio was significantly decrease in the treatment group (average proportion of Th17; 0.93 vs. $0.43 \%$; $\mathrm{P}=0.001$; ratio of Th17/Treg, 0.48 vs. $0.12 ; \mathrm{P}=0.001$ ) and the control group (mean percentage of Th17, 0.92 vs. $0.65 \%$; $\mathrm{P}=0.001$; ratio of Th17/Treg, 0.32 vs. $0.17 ; \mathrm{P}=0.001$ ) when compared with those before therapy (77). The decline in the number of Th17 cell displayed a substantial increase in the treatment group 


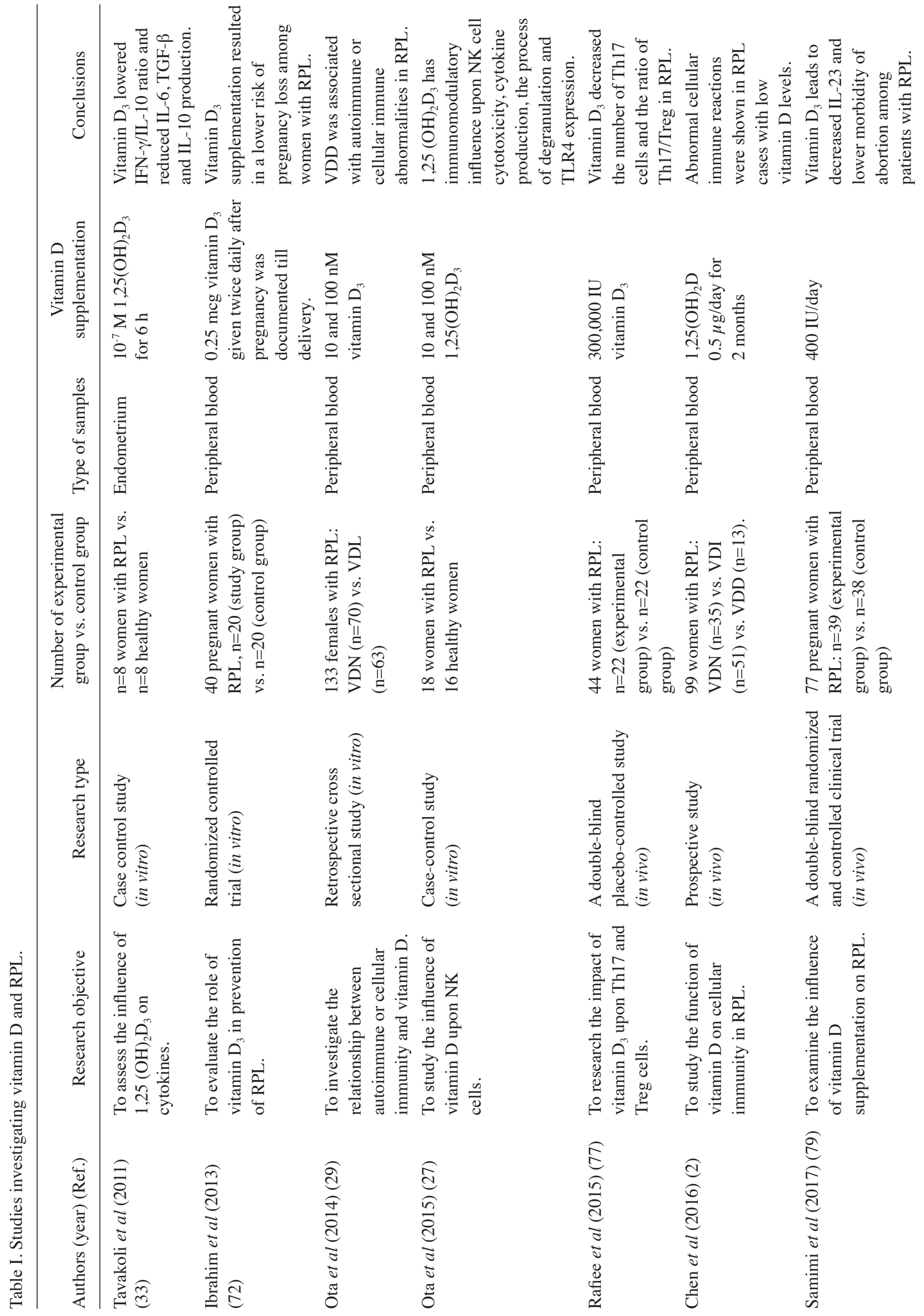


compared with the control group relative to the baseline values, and the decline in the ratio of Th17/Treg showed a significant enhancement in the treatment group when compared with the controls (77).

Further research revealed an association between the ratio of Treg/Th17 and vitamin D, as well as the impact on the balance between Treg and Th17, among patients with RPL who were given vitamin D (76). This study found that the expression of vitamin $\mathrm{D}$ had a strong association with the proportion of Treg cells, a negative association with the proportion of Th17 cells and a positive association with the ratio of Treg to Th17 in the RPL group (76). Moreover, the results were reversed in the control group (76). It has also been revealed that, relative to the control decidual tissues, 25(OH) D was significantly decreased among patients with RPL (78). Furthermore, correlation analysis indicated that there was a significantly negative correlation between $25(\mathrm{OH}) \mathrm{D}$ and IL-23. On the contrary, IL-23 increased the expression of IL-17 (78). Vitamin D can also be a beneficial medication by decreasing the amount of IL-23 (78). In addition, a study analyzing the impact of women with RPL given vitamin D found that vitamin D could decrease not only serum IL-23 but also the frequency of miscarriage (79).

\section{Vitamin D and peripheral NK cells in RPL}

Increased NK cells in the peripheral blood can lead to RPL (80). A previous retrospective cross-sectional study has reported that VDD may regulate cell immunity (29). Moreover, VDD may serve regulatory roles in peripheral NK cells (29). Significant differences have been identified in $\mathrm{CD}^{2} 6^{+} \mathrm{NK}$ cell levels from the peripheral blood between $\operatorname{VDL}(n=63)$ and VDN $(n=70)$ cases with RPL $(\mathrm{P}<0.05)(29)$. In VDD $(n=22)$, a significant increase of peripheral NK cell cytotoxicity has been indicated compared with that in the VDN group $(n=70)$ (29). After the vitamin D supplement, the cytotoxicity of NK cells from peripheral blood was significantly inhibited in a dose-dependent manner, when compared with the controls (29). Another study suggested that $1,25(\mathrm{OH})_{2} \mathrm{D}_{3}$ exerted an immunomodulatory impact on NK cell cytotoxicity, the secretion of cytokines, including Toll-like receptor 4 expression, and the degranulation process in RPL peripheral blood samples (27). In women with RPL, $1,25(\mathrm{OH})_{2} \mathrm{D}_{3}$ supplementation substantially decreased peripheral NK cell cytotoxicity compared with that of the vehicle group which was given reconstitution agent ethanol $(\mathrm{P}<0.01)(27)$. Previous research has also observed a substantial rise in peripheral NK cytotoxicity between VDI $(n=51)$ and VDN ( $\mathrm{n}=35$ ) cases (2). Moreover, peripheral NK cell cytotoxicity was significantly decreased after $1,25(\mathrm{OH})_{2} \mathrm{D}_{3}$ treatment compared with the levels prior to treatment (2). However, no obvious distinction was found in the percentage of $\mathrm{CD} 3{ }^{-} \mathrm{CD} 56^{+} \mathrm{NK}$ cells among three groups, VDN, VDI and VDD, before and after treatment (2). Therefore, it can be concluded that the effect of vitamin D on the count or cytotoxicity of NK cells tends to be independent (2). Taken together, a sufficient amount of vitamin D was found to be critical in regulating NK cell cytotoxicity in peripheral blood from patients with RPL. 


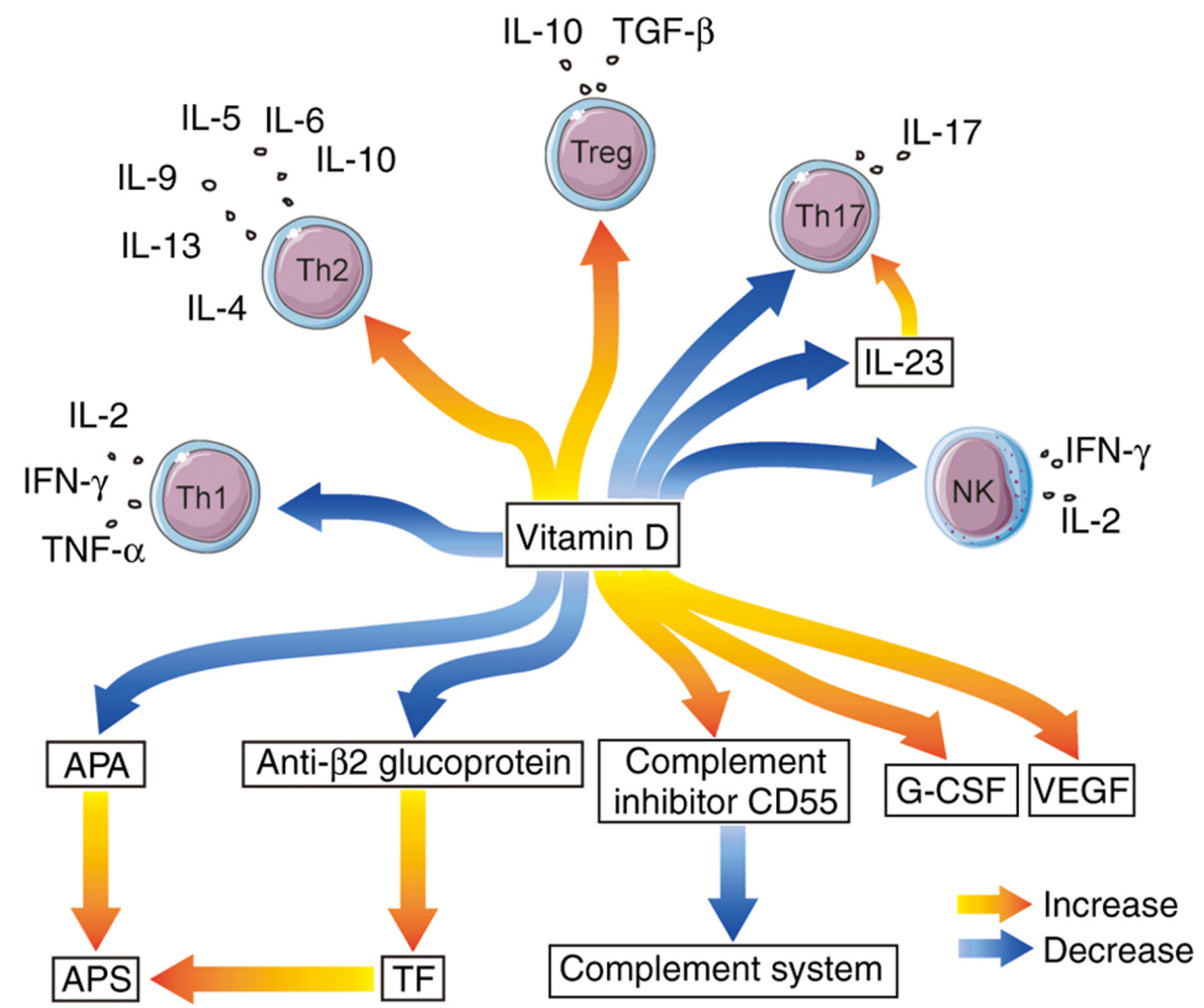

Figure 1. Immune impact of vitamin D on RPL. Vitamin D suppresses cytokines produced by Th1 cells and promotes cytokines secreted by Th2 cells. Moreover, vitamin D increases the function of Treg cells, whereas it reduces the number of Th17 cells, which secrete IL-17. Vitamin D is negatively correlated with IL-23, while IL-23 is positively associated with IL-17. Peripheral NK cell activation and its cytotoxic actions are inhibited by vitamin D. Vitamin D inhibits peripheral NK cytotoxicity by suppressing IFN- $\gamma$ and IL-2. VEGF and G-CSF production are stimulated by vitamin D. Vitamin D promotes the proliferation of the complement inhibitor CD55 and inhibits anti- $\beta 2$ glycoprotein. By inhibiting TF and APAs, vitamin D can prevent the occurrence of APS in RPL. RPL, recurrent pregnant loss; G-CSF, granulocyte colony-stimulating factor; TF, tissue factor; APS, antiphospholipid syndrome; APAs, antiphospholipid antibodies; Treg, regulatory T; Th, T helper; NK, natural killer.

\section{Vitamin D and cytokines in RPL}

It has been reported that the levels of VEGF and granulocyte colony-stimulating factor (G-CSF) can be induced by vitamin $D$ in NK cells (29). These two factors may induce weak angiogenesis and complications of pregnancy; for instance, in RPL, NK cells decrease the production of VEGF at the maternal fetal interface (29). The receptor of G-CSF exists in the trophoblast cells. It has been identified that G-CSF exerts significant impacts on autocrine and paracrine activities in both the decidua and placenta, and increased G-CSF markedly decreased the risk of pregnancy loss in a human trial (81). Vitamin D could also be a possible therapeutic alternative to avoid RPL by increasing the levels of VEGF and G-CSF.

\section{Conclusions}

In conclusion, vitamin D can significantly affect both autoimmunity and cellular immunity in RPL based on previously published studies (Table I; Fig. 1). Vitamin D is proposed to be available as a potential therapy for RPL. For patients with RPL or high risk factors, appropriate vitamin D supplement could be given, and the serological level of vitamin D should be detected regularly to obtain favorable maternal and fetal outcomes. In the future, a larger multicenter, prospective controlled study with a larger sample size is required.

\section{Acknowledgements}

Not applicable.

\section{Funding}

This manuscript was funded by Natural Science Foundation of Liaoning Province (grant no. 2020-MS-167).

\section{Availability of data and materials}

Not applicable.

\section{Authors' contributions}

$\mathrm{HZ}$ and $\mathrm{XW}$ wrote the manuscript, and $\mathrm{XY}$ revised this manuscript. All authors read and approved the final version.

\section{Ethics approval and consent to participate}

Not applicable.

\section{Patient consent for publication}

Not applicable. 


\section{Competing interests}

The authors declare that they have no competing interests.

\section{References}

1. Muyayalo KP, Li ZH, Mor G and Liao AH: Modulatory effect of intravenous immunoglobulin on Th17/Treg cell balance in women with unexplained recurrent spontaneous abortion. Am J Reprod Immunol 80: e13018, 2018.

2. Chen X, Yin B, Lian RC, Zhang T, Zhang HZ, Diao LH, Li YY, Huang CY, Liang DS and Zeng Y: Modulatory effects of vitamin D on peripheral cellular immunity in patients with recurrent miscarriage. Am J Reprod Immunol 76: 432-438, 2016.

3. Yang X, Yang E, Wang WJ, He Q, Jubiz G, Katukurundage D, Dambaeva S, Beaman K and Kwak-Kim J: Decreased HLA-C1 alleles in couples of KIR2DL2 positive women with recurrent pregnancy loss. J Reprod Immunol 142: 103186, 2020

4. Yan X, Wang L, Yan C, Zhang X, Hui L, Sheng Q, Xue M and Yu X Decreased expression of the vitamin $\mathrm{D}$ receptor in women with recurrent pregnancy loss. Arch Biochem Biophys 606: 128-133, 2016.

5. Jeve YB and Davies W: Evidence-based management of recurrent miscarriages. J Hum Reprod Sci 7: 159-169, 2014.

6. Rand JH, Wu XX, Andree HA, Lockwood CJ, Guller S, Scher J and Harpel PC: Pregnancy loss in the antiphospholipid-antibody syndrome-a possible thrombogenic mechanism. N Engl J Med 337: 154-160, 1997.

7. Mecacci F, Parretti E, Cioni R, Lucchetti R, Magrini A, La Torre P, Mignosa M, Acanfora L and Mello G: Thyroid autoimmunity and its association with non-organ-specific antibodies and subclinical alterations of thyroid function in women with a history of pregnancy loss or preeclampsia. J Reprod Immunol 46: 39-50, 2000.

8. Cavalcante MB, Cavalcante C, Sarno M, da Silva ACB and Barini R: Antinuclear antibodies and recurrent miscarriage: Systematic review and meta-analysis. Am J Reprod Immunol 83: e13215, 2020

9. Sakthiswary R, Rajalingam S, Norazman MR and Hussein $\mathrm{H}$ : Antinuclear antibodies predict a higher number of pregnancy loss in unexplained recurrent pregnancy loss. Clin Ter 166 e98-e101, 2015.

10. Kwak JY, Beaman KD, Gilman-Sachs A, Ruiz JE, Schewitz D and Beer AE: Up-regulated expression of $\mathrm{CD}^{+} 6^{+}, \mathrm{CD}^{2} 6^{+} / \mathrm{CD} 6^{+}$ and $\mathrm{CD} 19^{+}$cells in peripheral blood lymphocytes in pregnant women with recurrent pregnancy losses. Am J Reprod Immunol 34: 93-99, 1995.

11. Aoki K, Kajiura S, Matsumoto Y, Ogasawara M, Okada S Yagami Y and Gleicher N: Preconceptional natural-killer-cell activity as a predictor of miscarriage. Lancet 345: 1340-1342, 1995

12. Yougbaré I, Tai WS, Zdravic D, Oswald BE, Lang S, Zhu G, Leong-Poi H, Qu D, Yu L, Dunk C, et al: Activated NK cells cause placental dysfunction and miscarriages in fetal alloimmune thrombocytopenia. Nat Commun 8: 224, 2017.

13. Sasaki Y, Sakai M, Miyazaki S, Higuma S, Shiozaki A and Saito S: Decidual and peripheral blood $\mathrm{CD} 4{ }^{+} \mathrm{CD} 25^{+}$regulatory $\mathrm{T}$ cells in early pregnancy subjects and spontaneous abortion cases. Mol Hum Reprod 10: 347-353, 2004.

14. Stricker RB Steinleitner A and Winger EE: Intravenous immunoglobulin (IVIG) therapy for immunologic abortion. Clin Appl Immunol Rev 2: 187-199, 2002.

15. Bansal AS, Bajardeen B and Thum MY: The basis and value of currently used immunomodulatory therapies in recurrent miscarriage. J Reprod Immunol 93: 41-51, 2012.

16. Novac N, Baus D, Dostert A and Heinzel T: Competition between glucocorticoid receptor and NFkappaB for control of the human FasL promoter. FASEB J 20: 1074-1081, 2006.

17. Pasquier E, de Saint-Martin L, Marhic G, Chauleur C, Bohec C, Bretelle F, Lejeune-Saada V, Hannigsberg J, Plu-Bureau G, Cogulet V, et al: Hydroxychloroquine for prevention of recurrent miscarriage: Study protocol for a multicentre randomised placebo-controlled trial BBQ study. BMJ Open 9: e025649, 2019.

18. Lee SK, Kim JY, Han AR, Hur SE, Kim CJ, Kim TH, Cho BR, Han JW, Han SG, Na BJ and Kwak-Kim J: Intravenous immunoglobulin $\mathrm{G}$ improves pregnancy outcome in women with recurrent pregnancy losses with cellular immune abnormalities. Am J Reprod Immunol 75: 59-68, 2016.

19. Kim DJ,Lee SK, Kim JY, Na BJ, Hur SE, Lee M and Kwak-Kim J: Intravenous immunoglobulin $\mathrm{G}$ modulates peripheral blood Th17 and Foxp3(+) regulatory $\mathrm{T}$ cells in pregnant women with recurrent pregnancy loss. Am J Reprod Immunol 71: 441-450, 2014.
20. Kwak JY, Quilty EA, Gilman-Sachs A, Beaman KD and Beer AE: Intravenous immunoglobulin infusion therapy in women with recurrent spontaneous abortions of immune etiologies. J Reprod Immunol 28: 175-188, 1995

21. Han AR, Ahn H, Vu P, Park JC, Gilman-Sachs A, Beaman K and Kwak-Kim J: Obstetrical outcome of anti-inflammatory and anticoagulation therapy in women with recurrent pregnancy loss or unexplained infertility. Am J Reprod Immunol 68: 418-427, 2012.

22. Schwab I and Nimmerjahn F: Intravenous immunoglobulin therapy: How does IgG modulate the immune system? Nat Rev Immunol 13: 176-189, 2013.

23. Hutton B, Sharma R, Fergusson D, Tinmouth A, Hebert P, Jamieson $\mathrm{J}$ and Walker M: Use of intravenous immunoglobulin for treatment of recurrent miscarriage: A systematic review. BJOG 114: 134-142, 2007

24. Panda DK, Miao D, Tremblay ML, Sirois J, Farookhi R, Hendy GN and Goltzman D: Targeted ablation of the 25-hydroxyvitamin D 1alpha-hydroxylase enzyme: Evidence for skeletal, reproductive, and immune dysfunction. Proc Natl Acad Sci USA 98: 7498-7503, 2001

25. Brannon PM: Vitamin D and adverse pregnancy outcomes: Beyond bone health and growth. Proc Nutr Soc 71: 205-212, 2012.

26. Mora JR, Iwata M and von Andrian UH: Vitamin effects on the immune system: Vitamins A and D take centre stage. Nat Rev Immunol 8: 685-698, 2008.

27. Ota K,Dambaeva S,KimMW,Han AR,Fukui A, Gilman-Sachs A, Beaman K and Kwak-Kim J: 1,25-dihydroxy-vitamin D3 regulates NK-cell cytotoxicity, cytokine secretion, and degranulation in women with recurrent pregnancy losses. Eur J Immunol 45: 3188-3199, 2015.

28. Mulligan ML, Felton SK, Riek AE and Bernal-Mizrachi C: Implications of vitamin D deficiency in pregnancy and lactation. Am J Obstet Gynecol 202: 429.e1-e9, 2010.

29. Ota K, Dambaeva S, Han AR, Beaman K, Gilman-Sachs A and Kwak-Kim J: Vitamin D deficiency may be a risk factor for recurrent pregnancy losses by increasing cellular immunity and autoimmunity. Hum Reprod 29: 208-219, 2014.

30. Lee SK, Na BJ, Kim JY, Hur SE, Lee M, Gilman-Sachs A and Kwak-Kim J: Determination of clinical cellular immune markers in women with recurrent pregnancy loss. Am J Reprod Immunol 70: 398-411, 2013

31. Fukui A, Kwak-Kim J, Ntrivalas E, Gilman-Sachs A, Lee SK and Beaman K: Intracellular cytokine expression of peripheral blood natural killer cell subsets in women with recurrent spontaneous abortions and implantation failures. Fertil Steril 89: 157-165, 2008.

32. Ford HB and Schust DJ: Recurrent pregnancy loss: Etiology, diagnosis, and therapy. Rev Obstet Gynecol 2: 76-83, 2009.

33. Tavakoli M, Jeddi-Tehrani M, Salek-Moghaddam A, Rajaei S, Mohammadzadeh A, Sheikhhasani S, Kazemi-Sefat GE and Zarnani AH: Effects of 1,25(OH)2 vitamin D3 on cytokine production by endometrial cells of women with recurrent spontaneous abortion. Fertil Steril 96: 751-757, 2011.

34. Lagana AS, Vitale SG, Ban Frangez H, Vrtacnik-Bokal E and D'Anna R: Vitamin D in human reproduction: The more, the better? An evidence-based critical appraisal. Eur Rev Med Pharmacol Sci 21: 4243-4251, 2017.

35. Chighizola CB, de Jesus GR and Branch DW: The hidden world of anti-phospholipid antibodies and female infertility: A literature appraisal. Autoimmun Rev 15: 493-500, 2016.

36. Cyprian F, Lefkou E, Varoudi K and Girardi G: Immunomodulatory effects of Vitamin D in pregnancy and beyond. Front Immunol 10: 2739, 2019.

37. Carp HJ and Shoenfeld Y: Anti-phospholipid antibodies and infertility. Clin Rev Allergy Immunol 32: 159-161, 2007.

38. Redecha P, Franzke CW, Ruf W, Mackman N and Girardi G: Neutrophil activation by the tissue factor/Factor VIIa/PAR2 axis mediates fetal death in a mouse model of antiphospholipid syndrome. J Clin Invest 118: 3453-3461, 2008.

39. Tobaldini LQ, Arantes FT, Saraiva SDS, Mazetto BM, Colella MP, de Paula EV, Annichino-Bizzachi J and Orsi FA: Circulating levels of tissue factor and the risk of thrombosis associated with antiphospholipid syndrome. Thromb Res 171: 114-120, 2018

40. Tedesco F, Borghi MO, Gerosa M, Chighizola CB, Macor P, Lonati PA, Gulino A, Belmonte B and Meroni PL: Pathogenic role of complement in antiphospholipid syndrome and therapeutic implications. Front Immunol 9: 1388, 2018. 
41. Oku K, Atsumi T, Bohgaki M, Amengual O, Kataoka $\mathrm{H}$, Horita T, Yasuda S and Koike T: Complement activation in patients with primary antiphospholipid syndrome. Ann Rheum Dis 68: 1030-1035, 2009.

42. Breen KA, Seed P, Parmar K, Moore GW, Stuart-Smith SE and Hunt BJ: Complement activation in patients with isolated antiphospholipid antibodies or primary antiphospholipid syndrome. Thromb Haemost 107: 423-429, 2012.

43. De Carolis S, Botta A, Santucci S, Salvi S, Moresi S, Di Pasquo E, Del Sordo G and Martino C: Complementemia and obstetric outcome in pregnancy with antiphospholipid syndrome. Lupus 21: 776-778, 2012.

44. Reggia R, Ziglioli T, Andreoli L, Bellisai F, Iuliano A, Gerosa M, Ramoni V, Tani C, Brucato A, Galeazzi M, et al: Primary anti-phospholipid syndrome: Any role for serum complement levels in predicting pregnancy complications? Rheumatology (Oxford) 51: 2186-2190, 2012.

45. Girardi G, Berman J, Redecha P, Spruce L, Thurman JM, Kraus D, Hollmann TJ, Casali P, Caroll MC, Wetsel RA, et al: Complement $\mathrm{C} 5$ a receptors and neutrophils mediate fetal injury in the antiphospholipid syndrome. J Clin Invest 112: 1644-1654, 2003.

46. Redecha P, Tilley R, Tencati M, Salmon JE, Kirchhofer D, Mackman N and Girardi G: Tissue factor: A link between C5a and neutrophil activation in antiphospholipid antibody induced fetal injury. Blood 110: 2423-2431, 2007.

47. Izban MG, Nowicki BJ and Nowicki S: 1,25-Dihydroxyvitamin D3 promotes a sustained LPS-induced NF- $\mathrm{KB}$-dependent expression of CD55 in human monocytic THP-1 cells. PLoS One 7: e49318, 2012.

48. Agmon-Levin N, Blank M, Zandman-Goddard G, Orbach H, Meroni PL, Tincani A, Doria A, Cervera R, Miesbach W, Stojanovich L, et al: Vitamin D: An instrumental factor in the anti-phospholipid syndrome by inhibition of tissue factor expression. Ann Rheum Dis 70: 145-150, 2011.

49. van den Hoogen LL, van Roon JA, Radstake TR, Fritsch-Stork RD and Derksen RH: Delineating the deranged immune system in the antiphospholipid syndrome. Autoimmun Rev 15: 50-60, 2016.

50. Martinez-Moreno JM, Herencia C, Montes de Oca A, Muñoz-Castañeda JR, Rodríguez-Ortiz ME, Díaz-Tocados JM, Peralbo-Santaella E, Camargo A, Canalejo A, Rodriguez M, et al: Vitamin D modulates tissue factor and protease-activated receptor 2 expression in vascular smooth muscle cells. FASEB J 30: 1367-1376, 2016.

51. Santos TDS, Ieque AL, de Carvalho HC, Sell AM, Lonardoni MVC, Demarchi IG, de Lima Neto QA and Teixeira JJV: Antiphospholipid syndrome and recurrent miscarriage: A systematic review and meta-analysis. J Reprod Immunol 123: 78-87, 2017.

52. Matalon ST, Blank M, Ornoy A and Shoenfeld Y: The association between anti-thyroid antibodies and pregnancy loss. Am J Reprod Immunol 45: 72-77, 2001.

53. Poppe K, Velkeniers B and Glinoer D: Thyroid disease and female reproduction. Clin Endocrinol 66: 309-321, 2007.

54. Kivity S, Agmon-Levin N, Zisappl M, Shapira Y, Nagy EV, Dankó K, Szekanecz Z, Langevitz P and Shoenfeld Y: Vitamin D and autoimmune thyroid diseases. Cell Mol Immunol 8: 243-247, 2011

55. D'Aurizio F, Villalta D, Metus P, Doretto P and Tozzoli R: Is vitamin D a player or not in the pathophysiology of autoimmune thyroid diseases? Autoimmun Rev 14: 363-369, 2015

56. Shin DY, Kim KJ, Kim D, Hwang S and Lee EJ: Low serum vitamin $\mathrm{D}$ is associated with anti-thyroid peroxidase antibody in autoimmune thyroiditis. Yonsei Med J 55: 476-481, 2014.

57. Bhattacharyya R, Mukherjee K, Das A, Biswas MR, Basunia SR and Mukherjee A: Anti-thyroid peroxidase antibody positivity during early pregnancy is associated with pregnancy complications and maternal morbidity in later life. J Nat Sci Biol Med 6: 402-405, 2015.

58. Ozkan S, Jindal S, Greenseid K, Shu J, Zeitlian G, Hickmon C and Pal L: Replete vitamin D stores predict reproductive success following in vitro fertilization. Fertil Steril 94: 1314-1319, 2010.

59. Daftary GS and Taylor HS: Endocrine regulation of HOX genes. Endocrine Rev 27: 331-355, 2006.

60. Cippitelli M and Santoni A: Vitamin D3: A transcriptional modulator of the interferon-gamma gene. Eur J Immunol 28: 3017-3030, 1998.

61. Takeuchi A, Reddy GS, Kobayashi T, Okano T, Park J and Sharma S: Nuclear factor of activated T cells (NFAT) as a molecular target for 1alpha,25-dihydroxyvitamin D3-mediated effects. J Immunol 160: 209-218, 1998.
62. van Etten E and Mathieu C: Immunoregulation by 1,25-dihydroxyvitamin D3: Basic concepts. J Steroid Biochem Mol Biol 97: 93-101, 2005.

63. Piccinni MP, Scaletti C, Maggi E and Romagnani S: Role of hormone-controlled Th1- and Th2-type cytokines in successful pregnancy. J Neuroimmunol 109: 30-33, 2000.

64. Adams JS and Hewison M: Unexpected actions of vitamin D: New perspectives on the regulation of innate and adaptive immunity. Nat Clin Pract Endocrinol Metab 4: 80-90, 2008.

65. Boonstra A, Barrat FJ, Crain C, Heath VL, Savelkoul HF and O'Garra A: 1alpha,25-Dihydroxyvitamin d3 has a direct effect on naive CD4(+) T cells to enhance the development of Th2 cells. J Immunol 167: 4974-4980, 2001.

66. Overbergh L, Decallonne B, Waer M, Rutgeerts O, Valckx D, Casteels KM, Laureys J, Bouillon $\mathrm{R}$ and Mathieu C: 1alpha,25-dihydroxyvitamin D3 induces an autoantigen-specific T-helper 1/T-helper 2 immune shift in NOD mice immunized with GAD65 (p524-543). Diabetes 49: 1301-1307, 2000.

67. Gonçalves DR, Braga A, Braga J and Marinho A: Recurrent pregnancy loss and vitamin D: A review of the literature. Am J Reprod Immunol 80: e13022, 2018.

68. Peterson CA and Heffernan ME: Serum tumor necrosis factor-alpha concentrations are negatively correlated with serum $25(\mathrm{OH}) \mathrm{D}$ concentrations in healthy women. J Inflamm (Lond) 5: 10, 2008.

69. Abdollahi E, Saghafi N, Rezaee SA, Rastin M, Jarahi L, Clifton V and Rafatpanah H: Evaluation of 1,25(OH)2D3 Effects on FOXP3, ROR- $\gamma$ t, GITR, and CTLA-4 Gene expression in the PBMCs of Vitamin D-Deficient Women with unexplained recurrent pregnancy loss (URPL). Iran Biomed J 24: 295-305, 2020.

70. Holick MF, Binkley NC, Bischoff-Ferrari HA, Gordon CM, Hanley DA, Heaney RP, Murad MH and Weaver CM; Endocrine Society: Evaluation, treatment, and prevention of vitamin D deficiency: An Endocrine Society clinical practice guideline. J Clin Endocrinol Metab 96: 1911-1930, 2011.

71. Jeffery LE, Burke F, Mura M, Zheng Y, Qureshi OS, Hewison M, Walker LS, Lammas DA, Raza K and Sansom DM: 1,25-Dihydroxyvitamin D3 and IL-2 combine to inhibit T cell production of inflammatory cytokines and promote development of regulatory T cells expressing CTLA-4 and FoxP3. J Immunol 183: 5458-5467, 2009.

72. Ibrahim ZM, madany EH, Abdel Aal RM and El Biely MM: Role of 1,25-dihydroxyvitamin D (vitamin D3) as immunomodulator in recurrent missed miscarriage. Middle East Fertility Soc J 18: 171-176, 2013

73. Figueiredo AS and Schumacher A: The T helper type 17/regulatory T cell paradigm in pregnancy. Immunology 148: 13-21, 2016.

74. Vijayendra Chary A, Hemalatha R, Seshacharyulu M, Vasudeva Murali M,Jayaprakash D and Dinesh Kumar B: Vitamin D deficiency in pregnant women impairs regulatory $\mathrm{T}$ cell function. J Steroid Biochem Mol Biol 147: 48-55, 2015.

75. Abdollahi E, Rezaee R, Saghafi N, Rastin M, Clifton V, Sahebkar A and Rafatpanah $\mathrm{H}$ : Evaluation of the effects of 1,25 vitamin D3 on regulatory $\mathrm{T}$ cells and $\mathrm{T}$ helper 17 cells in Vitamin D-deficient women with unexplained recurrent pregnancy loss. Curr Mol Pharmacol 13: 306-317, 2020.

76. Ji J, Zhai H, Zhou H, Song S, Mor G and Liao A: The role and mechanism of vitamin D-mediated regulation of Treg/Th17 balance in recurrent pregnancy loss. Am J Reprod Immunol 81: e13112, 2019.

77. Rafiee M, Gharagozloo M, Ghahiri A, Mehrabian F, Maracy MR, Kouhpayeh S, Pieper IL and Rezaei A: Altered Th17/Treg ratio in recurrent miscarriage after treatment with paternal lymphocytes and Vitamin D3: A Double-blind placebo-controlled study. Iran J Immunol 12: 252-262, 2015.

78. Li N, Wu HM, Hang F, Zhang YS and Li MJ: Women with recurrent spontaneous abortion have decreased $25(\mathrm{OH})$ vitamin $\mathrm{D}$ and VDR at the fetal-maternal interface. Braz J Med Biol Res 50: e6527, 2017.

79. Samimi M, Foroozanfard F, Amini F and Sehat M: Effect of Vitamin D supplementation on unexplained recurrent spontaneous abortion: A double-blind randomized controlled trial. Global J Health Sci 9: 95-102, 2017.

80. Yang X, Gilman-Sachs A and Kwak-Kim J: Ovarian and endometrial immunity during the ovarian cycle. J Reprod Immunol 133: 7-14, 2019.

81. Scarpellini F and Sbracia M: Use of granulocyte colony-stimulating factor for the treatment of unexplained recurrent miscarriage: A randomised controlled trial. Hum Reprod 24: 2703-2708, 2009.

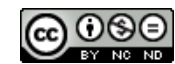

This work is licensed under a Creative Commons Attribution-NonCommercial-NoDerivatives 4.0 International (CC BY-NC-ND 4.0) License. 